\title{
A IMPORTÂNCIA DE ENSINAR RESISTÊNCIA BACTERIANA NO ENSINO MÉdIO: UMA ANÁLISE DE LIVROS DIDÁTICOS DE Biologia SELECIONADOS PELO PNLEM/2018
}

\author{
The Importance of Teaching Bacterial Resistance in High \\ SCHOOL - AN ANALYSIS OF BIOLOGY TEXTBOOKS SELECTED BY \\ PNLEM/2018
}

DOI: http://dx.doi.org/10.23926/RPD.2526-2149.2019.v4.n2.p653-668.id497

\section{Marcelle Alves \\ Carvalho \\ Mestranda em Ensino em \\ Ciências da Saúde e do Meio \\ Ambiente (UniFOA) \\ marcellealvescarvalho@yaho o.com.br}

\section{Carlos Alberto}

Sanches Pereira

Doutor em Biotecnologia

Industrial (USP)

Professor e orientador do

Programa de Mestrado em

Ensino em Ciências da

Saúde e do Meio Ambiente

(UniFOA)

sanches68@gmail.com

\section{Lidiane de Fátima de \\ Oliveira Souza}

Mestranda em Ensino em

Ciências da Saúde e do Meio

Ambiente (UniFOA)

lidianesouza856@gmail.com

\section{Ana Paula Cunha \\ Pereira}

Doutora em Educação Física (UNICAMP)

Professora e orientadora do Programa de Mestrado em Ensino em Ciências da Saúde e do Meio Ambiente (UniFOA)

acunhapereiraa@gmail.com
Resumo: O presente trabalho é fruto de uma pesquisa que investiga o tema da resistência bacteriana e suas relações com o campo do ensino e as discussões que tangem o tema da saúde, gerando o objetivo desta pesquisa: verificar o trato do tema resistência bacteriana, abordada em livros didáticos e sua explanação relativa a importância do uso correto de antibióticos. Para isso, lançamos mão de uma metodologia de cunho qualitativo, empreendendo um estudo descritivo de 10 (dez) livros didáticos de Biologia indicados pelo Programa Nacional do Livro Didático para o Ensino Médio (PNLEM/2018). A análise considerou a presença de quatro critérios: C1doenças bacterianas e seu tratamento; C2- Resistência Bacteriana; C3Problematização do tema Resistência Bacteriana; $\mathrm{C} 4$ - Incentivo as práticas de uso correto de antibióticos. Dos livros analisados $80 \%$ estão adequados quanto ao ensino de doenças bacterianas e tratamento. O tema resistência bacteriana apareceu em $50 \%$ dos livros com tópicos extremamente pequenos e explicações rasas. A problematização da resistência bacteriana apareceu em $70 \%$ dos livros com número de questões insignificantes. O uso correto de antibióticos apareceu somente em $40 \%$ dos livros. Concluímos que se faz necessário a criação de outras formas didáticas para o ensino destas temáticas em sala de aula.

Palavras-chave: Bactéria; Resistência bacteriana; Antibióticos; Ensino; Livro didático.

\begin{abstract}
The present work is the result of a research that investigates the theme of bacterial resistance and its relations with the teaching field and the discussions that address the health theme, generating the objective of this research: to verify the treatment of the bacterial resistance theme, addressed in books. didactics and their explanation of the importance of the correct use of antibiotics. For this, we used a qualitative methodology, undertaking a descriptive study of 10 (ten) biology textbooks indicated by the National Program of Textbook for High School (PNLEM / 2018). The analysis considered the presence of four criteria: $\mathrm{C} 1$ - bacterial diseases and their treatment; C2- Bacterial Resistance; C3- Problematization of the theme Bacterial Resistance; C4- I encourage the practices of correct use of antibiotics. Of the analyzed books $80 \%$ are adequate regarding the teaching of bacterial diseases and treatment. The topic bacterial resistance has appeared in $50 \%$ of books with extremely short topics and shallow explanations. The problematization of bacterial resistance appeared in $70 \%$ of the books with a number of insignificant questions. Correct use of antibiotics appeared in only $40 \%$ of the books. We conclude that it is necessary to create other didactic forms for the teaching of these themes in the classroom.
\end{abstract}

Keywords: Bacterium; Bacterial resistance; Antibiotics; Teaching; Textbook 


\section{INTRODUÇÃO}

O ensino contribui para desenvolver e moldar o ser humano de acordo com suas características históricas e culturais, além de ser um modo de socializar o ser humano no ambiente em que vive. Muitos são os ambientes em que se constrói o ensino, entre eles podese citar a família, a escola, a igreja e grupos sociais. Entretanto, a escola se destaca por capacitar o indivíduo a alçar uma vida profissional, sendo um ambiente de especialização e educação que propicia a integração ensino-educação-sociedade, desenvolvendo um ser humano preparado para a vida pública (SACRISTÁN \& GOMÉZ, 2009).

Há uma relação entre escola e saúde, onde a escola é considerada um local adequado para o desenvolvimento de promoção da saúde, com adoção de medidas educativas e preventivas, pois, por ser um ambiente extrafamiliar permite reforçar respostas sociais aprendidas em casa, representar novas, e até mesmo, restringir ou excluir algumas incorretas (OLIVEIRA et al, 2019).

Na promoção da saúde a escola é capaz de formar indivíduos mais conscientes no diaa-dia principalmente quando abordado o tema de microbiologia, que está diretamente relacionada à higiene pessoal e saúde, bem como a inúmeros outros aspectos relacionados ao funcionamento do meio ambiente. Este tema é o ramo da biologia dedicado ao estudo dos seres microscópicos como bactérias, fungos, vírus, protozoários e algas unicelulares (CASSANTI et al, 2008).

Desta forma, um aspecto importante que deve ser considerado no ensino de microbiologia é o uso indiscriminado de antibióticos, que ocasiona um aumento assustador no número de linhagens resistentes a esses medicamentos. Dentre os fenômenos que estão definitivamente vinculados ao crescimento da Resistência Bacteriana estão o uso abusivo, indiscriminado e/ou inadequado dos antibióticos. Tais aspectos, aliados aos avanços tecnológicos responsáveis pela facilidade de transporte de um microrganismo de um extremo a outro do planeta, justificam a importância do ensino de bactérias, resistência bacteriana e uso correto de antibióticos em escolas. Bem como é necessário o incentivo de políticas de saúde que minimizem a prática da automedicação, incentivando o uso racional e correto de antibióticos a fim de diminuir a incidência de problemas relacionados a esses medicamentos (CASSANTI et al, 2008; BRAIOS, 2013; MORAES et al, 2016).

De acordo com a Organização Mundial da Saúde (2012) durante várias décadas e em diferentes níveis as bactérias responsáveis por infecções comuns desenvolveram resistência a cada novo antibiótico criado, gerando uma ameaça à saúde mundial. Entretanto, com a escassez 
de novos antibióticos no mercado este tipo de situação tornou-se um problema crítico de saúde, necessitando de medidas preventivas urgentes para evitar uma crise global na área da saúde.

É nesse contexto que se deve produzir um ensino de Biologia cada vez mais voltado para uma leitura mais crítica da realidade, auxiliando os estudantes a tomar consciência dos problemas ambientais que são produzidos pelo modo de vida contemporâneo, com sérias consequências para a espécie humana, como a Resistência Bacteriana. Portanto, selecionar e organizar os conhecimentos a serem ensinados nas escolas de modo que contribuam para uma formação cidadã é imprescindível na formação dos estudantes (BRASIL, 2017).

Uma forma de organizar esses conhecimentos é através da utilização de livros didáticos, os quais são importantes ferramentas capazes de promover a reflexão sobre vários aspectos da realidade, orientar a condução da aula pelo professor e ainda estimular o sentimento de investigação do aluno. A seleção dos livros didáticos a serem utilizados é de grande importância para o aprendizado dos alunos e deve ser feita baseada no contexto real de vida dos estudantes, percebidos pelos seus respectivos professores. Com base nisso no ano de 2003 o MEC implantou, com a Resolução $n^{\circ} 38$ do Fundo Nacional para o Desenvolvimento da Educação (FNDE), o Programa Nacional do Livro Didático para o Ensino Médio (PNLEM), que prevê a distribuição de livros didáticos para os alunos do ensino médio público de todo o país, e a partir de 2006 começaram a serem distribuídos os livros didáticos de Biologia para os alunos do ensino médio do país (BRASIL, 2006; BATISTA et al, 2010).

Analisando a importância que a escola representa na promoção da saúde é imprescindível uma análise do comprometimento dos livros didáticos com a qualidade dos conteúdos presentes neste material, sobretudo com relação à atualização do conhecimento científico e à vinculação com a prática social dos professores e alunos. Neste sentido, o objetivo principal desta investigação é verificar o trato do tema resistência bacteriana, abordada em livros didáticos e sua explanação relativa a importância do uso correto de antibióticos.

\section{REFERENCIAL TEÓRICO}

A Resistência Bacteriana é um fenômeno relacionado ao surgimento de linhagens bacterianas não sensíveis, capazes de se multiplicar na presença de concentrações de antibióticos mais elevadas do que aquelas utilizadas na clínica. Apesar de a Resistência Bacteriana ocorrer naturalmente ao longo do tempo, o uso indevido e o uso excessivo de antibióticos estão acelerando esse processo. (MORAES et al, 2016; OMS, 2018). 
A Organização Mundial da Saúde (2018) vem alertando sobre a situação alarmante que a Resistência Bacteriana se encontra, colocando em risco as conquistas da medicina moderna. Em 2018 a OMS relatou que a resistência aos antibióticos está subindo a níveis perigosamente altos em todas as partes do mundo e que novos mecanismos de resistência estão surgindo e se espalhando globalmente, ameaçando a capacidade de tratar doenças infecciosas comuns. Uma lista crescente de infecções, entre elas pneumonia, tuberculose, bacteremia, gonorreia e doenças transmitidas por alimentos, estão se tornando cada vez mais difíceis de tratar, algumas vezes até impossível, à medida que os antibióticos se tornam menos eficazes.

As bactérias desenvolveram ao longo de sua exposição aos antibióticos diversas formas de Resistência Bacteriana. Dentre elas, há a produção de enzimas inativadoras capazes de inativar a atividade antibacteriana do fármaco. Esses microrganismos também são capazes de formar biofilmes, comunidades de células agregadas, organizadas e funcionais, capazes de tornar impermeável o fármaco. Ainda através de bombas de efluxo, que são proteínas específicas para a exportação de substâncias nocivas ao metabolismo celular, apresentam a capacidade de expulsar o fármaco de seu interior. E também devido à elevada atividade metabólica e reprodutiva bacteriana há ainda a capacidade de desenvolver formas de resistência intrínsecas através de mutações genéticas, e transferir os genes de resistência aos antibióticos a outras bactérias (OLIVEIRA \& SILVA, 2008).

Após o aparecimento, a Resistência Bacteriana é irreversível ou caracteriza-se por uma reversão muito lenta apesar da introdução de programas de contenção e vigilância. Portanto, uma política de saúde pública eficaz é aquela realizada para evitar o desenvolvimento inicial e/ou a propagação dessa resistência através da implementação precoce de intervenções. De acordo com a OMS algumas medidas podem ser ensinadas a população a fim de prevenir e controlar a propagação da resistência aos antibióticos, entre elas: não fazer automedicação com antibióticos e usá-los apenas quando prescritos por um profissional de saúde certificado; nunca exigir antibióticos se o profissional de saúde disser que não é necessário; seguir sempre o conselho do profissional de saúde quando estiver usando antibióticos; nunca compartilhar ou usar antibióticos restantes; evitar infecções lavando as mãos regularmente, preparando alimentos de forma higiênica, evitando contato próximo com pessoas doentes, praticando sexo seguro e mantendo as vacinas atualizadas (OMS, 2012; OMS, 2018).

Em relação à automedicação, que é um dos pontos relacionados à promoção da Resistência Bacteriana, crianças e adolescentes representam um grupo fortemente predisposto ao uso irracional de medicamentos com e sem controle médico. Isto ocorre devido a vários 
fatores como a simbolização da saúde que o medicamento pode representar; publicidade irresponsável, baixa qualidade da assistência à saúde e a dificuldade de acesso aos serviços de saúde em países subdesenvolvidos. Assim, diferentes órgãos de saúde incentivam estratégias capazes de impedir o uso irracional de medicamentos, nos mais diversos ambientes, como instrumento de transformação das práticas inadequadas de saúde. Um destes ambientes pode ser a escola, pois a mesma é reconhecida como um espaço propício para tais atividades de promoção e prevenção, além de possuir uma responsabilidade social neste sentido (PEREIRA et al, 2007; DANDOLINI et al, 2012). Logo, o conhecimento a respeito das doenças bacterianas, sua proliferação e seu tratamento auxilia na conscientização do uso correto de antibióticos ajudando a prevenir e controlar a resistência bacteriana.

No espaço escolar um material muito importante e que serve como mediador dos processos educativos e trazem os conhecimentos científicos didatizados e transformados para o contexto escolar são os livros didáticos. Nesse sentido, eles têm a importante função de conectar a linguagem da Ciência com aquela do cotidiano, com a explícita intenção de promover a aprendizagem, e consequentemente uma melhora para a saúde pública (BRASIL, 2017).

A utilização do livro didático assume importância diferenciada de acordo com as condições, lugares e situações em que é produzido e utilizado nos diferentes âmbitos escolares. É necessário que professores estejam preparados para escolher adequadamente o livro didático a ser utilizado em suas aulas, pois ele será auxiliador na aprendizagem dos estudantes, visto que essa ferramenta se constitui numa importante fonte de estudo e pesquisa para esses; e o único instrumento de apoio do professor na realidade da maioria das escolas (FRISON et al, 2009, p.3).

\section{Metodologia}

A pesquisa em questão é de cunho qualitativo, empreendendo um estudo descritivo. A opção por essa dimensão metodológica está intimamente relacionada ao:

\footnotetext{
Compromisso epistemológico com uma concepção crítica educacional, partindo do pressuposto de que a realidade não pode ser entendida como uma construção independente do sujeito cognoscitivo, pois essa realidade é uma construção social subjetiva e intersubjetiva, marcada por um contexto histórico e influenciada por valores, culturais e econômicos (PÉREZ, 2012, p. 140).
}

É justamente sob a prerrogativa da construção atrelada ao sujeito e no caso dessa pesquisa em particular trata-se dos usuários diretos do livro didático no contexto do ensino que, notamos a necessidade de relacionar a teoria (empreendida na elaboração dos referidos livros) 
com a prática (compreendida como a aplicabilidade dos temas desenvolvidos na educação básica).

Desse modo, foram analisados dez livros didáticos de Biologia apontados pelo PNLEM 2018 com o volume correspondente ao tema de bacteriologia (Quadro 1) sendo que, tal tema encontra-se preferencialmente nos livros didáticos do segundo ano do Ensino Médio.

Quadro 1 - Lista de livros didáticos selecionados pelo PNLEM-2018 analisados neste artigo

\begin{tabular}{|c|c|c|c|c|}
\hline Livro & Obra & Autores & Editora & $\begin{array}{c}\text { Ano } \\
\text { de } \\
\text { edição }\end{array}$ \\
\hline 1 & Biologia hoje vol. 2 & $\begin{array}{c}\text { Fernando Gerwandsznajder, } \\
\text { Sérgio Linhares e Helena } \\
\text { Pacca }\end{array}$ & Ática & 2016 \\
\hline 2 & $\begin{array}{c}\text { Integralis - biologia: novas bases } \\
\text { vol. } 2\end{array}$ & Nélio Bizzo & IBEP & 2016 \\
\hline 3 & Ser protagonista - biologia vol.2 & André Catani, et al. & SM & 2016 \\
\hline 4 & $\begin{array}{c}\text { Biologia- unidade e diversidade } \\
\text { vol. } 2\end{array}$ & José Arnaldo Favaretto & FTD & 2016 \\
\hline 5 & $\begin{array}{c}\text { Biologia moderna - amabis \& } \\
\text { martho vol. } 2\end{array}$ & $\begin{array}{l}\text { Gilberto Rodrigues Martho; } \\
\text { José Mariano Amabis }\end{array}$ & Moderna & 2016 \\
\hline 6 & Conexões com a biologia vol.2 & $\begin{array}{c}\text { Obra coletiva. Editora Rita } \\
\text { Helena Bröckelmann }\end{array}$ & Moderna & 2016 \\
\hline 7 & Biologia vol.2 & Vivian L. Mendonça & AJS & 2016 \\
\hline 8 & Bio vol. 2 & $\begin{array}{c}\text { Sônia Lopes \& Sérgio } \\
\text { Rosso }\end{array}$ & Saraiva & 2016 \\
\hline 9 & Biologia vol.2 & $\begin{array}{l}\text { César da Silva Junior, Sezar } \\
\text { Sasson, Nelson Caldine }\end{array}$ & Saraiva & 2016 \\
\hline 10 & \# Contato biologia & $\begin{array}{c}\text { Marcela Ogo \& Leandro } \\
\text { Godoy }\end{array}$ & Quinteto & 2016 \\
\hline
\end{tabular}

Fonte: PNLD 2018: Biologia - guia de livros didáticos - Ensino Médio/ Ministério da Educação (BRASIL, 2017).

A relação destes autores e obras estão organizadas por referência numérica de 1 a 10 de acordo com o Quadro 1. A análise de cada livro foi realizada nos capítulos referente ao Reino Monera e buscou-se analisar principalmente a abordagem do tema Resistência bacteriana e sua problematização; bem como o uso correto de antibióticos e a abordagem das doenças bacterianas e seu tratamento.

Para tal propósito, estabeleceu-se critérios de avaliação para a coleta desses dados nos livros didáticos, apresentados no Quadro 2. 
Quadro 2 - Critérios de avaliação dos livros didáticos de Biologia acerca do assunto Bacteriologia

\begin{tabular}{|l|}
\hline \multicolumn{1}{|c|}{ Critérios de avaliação } \\
\hline C1 - Aborda doenças bacterianas e seu tratamento \\
\hline C2 - Abordagem de resistência bacteriana \\
\hline C3 - Problematização do tema a respeito de resistência bacteriana \\
\hline C4 - Incentivo as práticas de uso correto de antibióticos \\
\hline
\end{tabular}

Fonte: Elaborado pelos autores (2019).

\section{Resultados}

Abaixo estão apresentados os resultados obtidos da análise dos livros (Quadro 3), onde C significa o critério analisado de acordo com o Quadro 2, L significa o livro didático de acordo com o Quadro 1, e X significa que o livro contemplou o critério analisado.

\begin{tabular}{|c|c|c|c|c|c|c|c|c|c|c|}
\hline & L1 & L2 & L3 & L4 & L5 & L6 & L7 & L8 & L9 & L10 \\
\hline C1 & $X$ & $X$ & $X$ & $X$ & & $X$ & $X$ & $X$ & & $X$ \\
\hline $\mathrm{C} 2$ & $X$ & $X$ & $X$ & $X$ & & & & & & $X$ \\
\hline C3 & $X$ & & $X$ & & $X$ & $X$ & $X$ & $X$ & & $X$ \\
\hline $\mathrm{C} 4$ & $X$ & & & $X$ & & & $X$ & $X$ & & \\
\hline
\end{tabular}

Fonte: Elaborado pelos autores (2019).

\subsection{Critério 1 - Abordagem de doenÇAS baCterianas e SEU tratamento nos LIVROS DIDÁTICOS}

A bacteriologia é um tema importante a ser ensinado nas escolas ao passo que as bactérias desempenham um papel significativo na vida humana, afetando, interagindo e alterando o ambiente. As bactérias vivem na superfície e no interior de nosso corpo, compondo a microbiota humana. São vitais em muitas indústrias como de alimentos e bebidas. São essenciais para a produção e a reciclagem de certos elementos, como carbono, oxigênio e nitrogênio. São usados para remover resíduos tóxicos. São usadas em engenharia genética e terapia gênica. E, obviamente, muitas causam doenças (ENGELKIRK, 2012). As doenças infecciosas constituem a principal causa de morte no mundo. Em todo o mundo, as doenças infecciosas causam cerca de 50000 mortes por dia, sendo que a maioria das mortes ocorre em países em desenvolvimento (ENGELKIRK, 2012).

No livro didático 1 na parte de morfologia já é citado que a presença de fímbrias ajudam na adesão da bactéria às células do hospedeiro, facilitando a infecção. Neste livro didático 
também foi separado quase duas páginas para relatar algumas doenças causadas por bactérias, entre elas, hanseníase, tuberculose, meningite meningocócica, leptospirose e cólera. Além disso, no final de cada tópico foi explicado a forma de prevenção dessas doenças bacterianas, bem como que o tratamento das mesmas deveria ser feito com antibióticos.

O livro 2 aborda quase duas páginas de doenças infecciosas e seu tratamento, sendo que no mesmo há um quadro explicativo contendo oito tipos de infecções, a bactéria, seus principais sintomas e tratamentos que auxiliam o aprendizado do aluno. As doenças apresentadas foram tuberculose, pneumonia, enterite, leptospirose, difteria, coqueluche, peste bubônica e cólera.

Na página 31 do livro 3 explicam-se as doenças causadas por bactérias, sua transmissão e a forma de tratamento. Entre as doenças explicadas encontram-se a tuberculose, tétano, meningite bacteriana e diarreia infecciosa.

No livro 4 a abordagem de doenças bacterianas foi feita na pág. 31. Através de um quadro explicativo contendo a doença, agente etiológico, forma de transmissão, manifestações e prevenção, apresentando as seguintes doenças: pneumonia bacteriana, tuberculose, hanseníase, difteria, coqueluche, tétano, cólera e meningite.

No livro 5 a abordagem de doenças bacterianas e seus tratamentos foi insuficiente, pois foi exposto somente o que são os antibióticos e quando eles foram descobertos. Não foram expostas as doenças causadas por bactérias, nem a forma de transmissão e tratamento das mesmas.

O livro 6 apesar de abordar as doenças bacterianas não abordou as formas de tratamento de cada doença. As doenças apresentadas foram: tétano, botulismo, febre tifoide, tuberculose, cólera, leptospirose e sífilis; e os tópicos relacionados com estas doenças foram: agente causador, contágio e sintomas.

O livro 7 abordou em três páginas as doenças bacterianas, descrevendo cada doença, sua transmissão e seu tratamento; as doenças abordadas neste livro foram: cárie dentária, disenteria, meningite, hanseníase, tuberculose, tétano, cólera e sífilis. Além disto, este LD sugeriu aos alunos a pesquisa de uma das outras doenças bacterianas graves que não foram abordadas no livro, a fim de aumentar o conhecimento dos mesmos. Entre estas doenças importantes estavam: botulismo, leptospirose, febre maculosa, febre tifoide, o tifo, a difteria ou crupe, a gonorreia, o cancro mole e o linfogranuloma.

O livro 8 disponibiliza duas páginas para informar sobre doenças bacterianas, explicando seu modo de transmissão e medidas profiláticas a serem tomadas. O mesmo informa também que essas doenças podem ser tratadas com antibióticos. Dentre as doenças apresentadas 
estão: botulismo, cólera, coqueluche, difteria ou crupe, febre maculosa, hanseníase, leptospirose, meningite epidêmica, pneumonia bacteriana, sífilis, tétano e tuberculose.

O livro 9 não aborda doenças bacterianas e seu tratamento. Por sua vez, o livro 10 aborda as doenças bacterianas em duas páginas a partir da página 45. Nesta seção são abordadas as seguintes doenças: cárie, tétano, hanseníase, tuberculose, meningite, gonorreia, sífilis e clamídia, cólera e leptospirose. Em cada doença foi explicado o agente etiológico, a forma de transmissão, prevenção e o tratamento em geral com antibióticos. Nesta seção também foi apresentada uma abordagem geral de formas de prevenir a infecção:

\begin{abstract}
Algumas bactérias podem ser evitadas por meio de atitudes como escovar os dentes após as refeições e antes de dormir, lavar as mãos após utilizar o banheiro, beber somente água tratada. Além disso, é necessário procurar um médico sempre que houver suspeita de infecção (LOPES \& ROSSO, 2016, p.45).
\end{abstract}

\title{
4.2. CRITÉrio 2 - AbORDAGEM de RESISTÊNCIA BACTERIANA NOS LIVROS DIDÁtICOS
}

A resistência bacteriana aos antibióticos é uma fonte de grande preocupação desde os primórdios da utilização desse tipo de medicamento, pois ela aumenta o risco de eventos adversos, causa retardo de diagnósticos, pode mascarar certas doenças, impede a eficácia do tratamento e causa a demora na cura do paciente (MORAES et al, 2016). Por estes motivos a abordagem a respeito da resistência bacteriana é um ponto crucial à medida que o indivíduo aprende os prejuízos que este tema pode trazer a sua saúde e da sociedade.

O livro 1 começa abordando a existência da resistência bacteriana na página 28 no tópico de morfologia e fisiologia das bactérias, através do texto: “..., pode haver uma ou mais moléculas menores de DNA, os plasmídeos. Alguns podem conter genes que conferem à bactéria resistência a antibióticos;...”. Na parte de Reprodução Bacteriana há uma melhor explicação a respeito de como ocorre a transferência de resistência bacteriana de uma bactéria a outra:

A conjugação permite, por exemplo, espalhar a resistência a antibióticos entre as bactérias. Isso acontece quando um plasmídeo com um gene que confere resistência a determinado antibiótico é transferido. Desse modo, também podem surgir bactérias resistentes a vários tipos de antibióticos (LINHARES, 2016, p.28).

O livro 2 explica a resistência bacteriana causada pelo uso indiscriminado de antibióticos em vários trechos, como: "No entanto, o uso indiscriminado de antibióticos, incluindo a automedicação, pode contribuir para o desenvolvimento de populações de bactérias resistentes" (pág. 28). Outros trechos retirados do livro que retratam a explicação da resistência bacteriana são demonstrados abaixo: 


\begin{abstract}
Algumas bactérias naturalmente resistentes a antibióticos se multiplicaram enormemente por causa do uso indiscriminado dessas substâncias nas mais variadas situações. Na medida em que se extinguem as bactérias sensíveis, as resistentes constituíam populações cada vez maiores. Como vimos, elas tem mecanismos de transmissão de características genéticas entre si e, assim, hoje muitas bactérias são resistentes a esses antibióticos (BIZZO, 2016, p. 25).

Várias bactérias produzem substâncias capazes de anular o efeito de antibióticos. No entanto, em ambientes onde o antibiótico esteja presente, as demais linhagens não se reproduzem e grandes populações dessas bactérias se desenvolvem, aumentando muito o risco de se dispersar no ambiente e transmitir essa característica a bactérias antes sensíveis (BIZZO, 2016, p. 28).
\end{abstract}

No livro 3 a abordagem a resistência bacteriana foi realizada em dois tópicos, entre eles: “...os antibióticos usados podem causar efeitos colaterais. Esses são alguns dos principais motivos que levam o doente a abandonar o tratamento, favorecendo o surgimento de bacilos resistentes.” (pág. 31). A outra parte referente à resistência a antibióticos foi explicada em um quadro de 22 linhas com o título: Crescimento de resistência a antibióticos representa crise global de saúde, diz OMS. Neste quadro há um parágrafo que problematiza o uso errado de antibióticos com a resistência: “As principais causas do aumento desse fenômeno são a ingestão excessiva ou a interrupção do medicamento, além de falta de conhecimento sobre como usar (pág. 31)".

No livro 4 a Resistência Bacteriana foi abordada em um pequeno quadro como notícia através do seguinte trecho:

\footnotetext{
O uso excessivo de antibióticos é uma preocupação para médicos e para a Organização Mundial da Saúde (OMS), pois a prática contribui para a disseminação da resistência aos medicamentos. De acordo com um relatório da instituição divulgado no ano passado, essa condição é uma ameaça global à saúde pública (FAVARETTO, 2016, p.32).
}

O livro 7 apresentou um quadro "PENSE E RESPONDA" sugerindo que o alune busque conhecimento a respeito das superbactérias e produza um texto a respeito.

O livro 10 ao falar do glicocálice, presente em algumas bactérias, cita a resistência bacteriana: "essas estruturas desempenham papéis importantes, tais como: aumento da resistência bacteriana a diversos agentes antibacterianos, incluindo os antibióticos." (pág. 39). Nesta mesma página ao falar da presença de plasmídeos nas bactérias cita-se novamente a resistência a antibióticos: "Os genes presentes no DNA plasmidial não são essenciais para a sobrevivência da bactéria, mas podem trazer algumas vantagens competitivas, por exemplo, a presença de genes de resistência a antibióticos."

Ainda no livro 10 há outra explicação a respeito da aquisição de resistência bacteriana através da recombinação genética bacteriana: “A inserção ou perda de fragmentos de DNA nas bactérias ocorre de maneira frequente. Este processo está diretamente relacionado à aquisição 
de resistência a antibióticos." Abaixo neste mesmo trecho continua-se citando a resistência bacteriana: "Como a grande maioria dos genes que conferem resistência aos antibióticos está presente nos plasmídeos, a conjugação é um dos principais processos pelos quais bactérias sensíveis a antibióticos adquirem resistência contra eles.

No livro 5 não teve um parágrafo específico explicando o que é a resistência bacteriana. E no livro 6 também não teve uma abordagem da resistência bacteriana durante o capítulo. Os livros 8 e 9 também não abordaram o tema resistência bacteriana em seus conceitos.

\subsection{Critério 3 - Problematização do tema a Respeito de resistênCia BACTERIANA NOS LIVROS DIDÁTICOS}

A problematização do tema traz ao aluno a percepção da importância do conhecimento científico para a tomada de decisões individuais e coletivas, desenvolvendo habilidades para o estudo de Ciências como um processo de investigação e privilegiando situações de aprendizagem que possibilitam ao mesmo a formação de sua bagagem cognitiva (VASCONCELOS \& SOUTO, 2003). Esta é uma importante ferramenta de aprendizagem, pois alia o conhecimento a realidade prática do aluno, além de auxiliá-lo na tomada de decisões corretas como um cidadão consciente. Neste caso o estudo investigou como cada livro didático problematizou o uso de antibióticos relacionado à resistência bacteriana.

A problematização do tema resistência no livro 1 deu-se principalmente nos exercícios propostos. Entretanto, a quantidade de exercícios relacionada a este tema ainda é baixa, pois, de dezenove exercícios propostos, apenas dois referem-se à resistência bacteriana.

O livro didático 3 problematizou a resistência em dois pontos. Primeiro foi questionado "Porque o uso inadequado de antibióticos pode causar problema a toda a população, e não apenas ao indivíduo em tratamento? (pág.31)". E no segundo ponto o LD propõe a elaboração de um seminário pelos discentes a respeito das doenças causadas por bactérias em seres humanos, e neste aspecto foi citada a importância deste seminário: "uma vez que o tratamento com antibióticos pode selecionar linhagens de bactérias resistentes".

O livro 5 teve somente uma problematização a respeito deste tópico, onde o LD sugere em uma figura que o aluno discuta o termo superbactéria, porém sem explicar este assunto anteriormente. O livro 6 também teve uma problematização através de uma atividade proposta, onde foi solicitado a explicação de como este processo de resistência pode ocorrer. No livro 7 houve problematização com este tema, pois o livro trouxe dois exercícios a respeito. 
O livro 8 trouxe um exercício que inferia que um tipo de bactéria estava crescendo mesmo na presença do antibiótico provavelmente pela resistência a este antibiótico.

O livro 10 traz algumas atividades a respeito da resistência bacteriana, dentre elas há uma questão na pág. 46: “A conjugação bacteriana contribui para o aumento da resistência aos antibióticos? Justifique." Outra questão afirmou que um dos grandes problemas enfrentados pela medicina é a resistência aos antibióticos e pediu para o discente assinalar quais dos processos reprodutivos apresentados era o principal responsável pelas taxas de mutação desses seres vivos.

Já os livros 2, 4 e 9 não apresentam problematização referente ao termo resistência bacteriana.

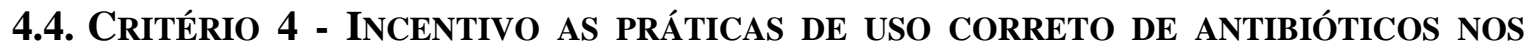 LIVROS DIDÁTICOS}

Outro De acordo com Moraes et al (2016) uma das medidas para amenizar o problema do uso incorreto de antibióticos seria instruir o usuário a fim de garantir que este faça a administração adequada e com segurança. Portanto o uso correto de antibióticos deve ser ensinado nas escolas, devendo este assunto estar contido principalmente nos livros didáticos, visto que é um tema de grande relevância para a saúde pública. No livro 1 menciona-se que o antibiótico só deve ser usado com orientação médica.

No livro 2 há uma explicação a respeito do uso indiscriminado, incluindo automedicação de antibióticos, que pode gerar a resistência bacteriana, ficando subentendido que os alunos não devem se automedicar e utilizar incorretamente os antibióticos. Entretanto não teve nenhuma citação a respeito da forma correta de utilizar esses medicamentos. Da mesma forma no livro 3 através das problematizações de resistência bacteriana percebe-se a intenção do LD em incentivar a prática do uso correto de medicamentos, mas isto não é totalmente explicito. $\mathrm{O}$ livro 6 não apresentou nenhum incentivo as práticas de uso correto de antibióticos.

No livro 4 teve incentivo às práticas de uso correto de antibióticos (pág. 37) em uma legenda de foto de antibiótico: "Os antibióticos (assim como outros medicamentos) devem ser tomados apenas sob orientação profissional, na dose e pelo período adequados, para que a infecção seja corretamente combatida e para se evitar a seleção de microrganismos resistentes.”.

No livro 5 não foi observado um tópico específico a respeito do uso correto de antibióticos, somente foi explicado as formas de prevenir as doenças bacterianas, como com o uso de vacinas e higienização. 
Por último o livro 7 também trouxe um incentivo ao uso correto de antibióticos através de uma frase: "Lembre-se de que o tratamento da sífilis, como de qualquer outra doença, deve ser orientado sempre pelo médico”. Incentivando desta forma o uso racional de antibióticos.

Na página 51 do livro 8 o mesmo sugere que: "O uso de antibióticos deve ser feito sob rígido controle médico". Em contraposto, os livros 9 e 10 não apresentam incentivo ao uso correto de antibióticos.

\section{CONSIDERAÇÕES FINAIS}

Levando-se em consideração a importância do conhecimento a respeito das doenças infecciosas, dos patógenos que as causam, das fontes dos patógenos, da maneira como essas doenças são transmitidas e sobre como proteger a si próprio, os livros estão apropriados, pois $80 \%$ dos livros analisados abordaram doenças bacterianas e seu tratamento. Eles descreveram com detalhes as doenças bacterianas mais importantes e enfatizaram a forma de tratá-las adequadamente; servindo este material didático como um potencial de cooperação para a construção de conhecimentos e formação cidadã nas ações de prevenção e controle de doenças bacterianas.

Através da análise da qualidade, quantidade e coerência científica da temática da resistência bacteriana presente nos livros de Biologia indicados pelo PNLEM 2018 percebe-se que apesar de $50 \%$ dos livros analisados abordarem este tema, muitos não atenderam às expectativas, pois abordaram este assunto em tópicos muito pequenos e com explicações rasas, levando o discente a aprender por conta própria quando do interesse do mesmo. Da mesma forma a problematização deste assunto apesar de aparecer em $70 \%$ dos livros, o número de problematizações nos livros foi escasso, em geral apresentando de uma a duas questões. $\mathrm{O}$ uso correto de antibióticos, um dos pontos principais para se evitar a resistência bacteriana, também não foi abordado com tanta relevância, pois só apareceu em $40 \%$ dos livros analisados.

Portanto, após a análise detalhada do tema resistência bacteriana e outros temas relacionados como o uso correto de antibióticos, conhecimento científico de doenças bacterianas e seu tratamento, conclui-se que apesar dos livros didáticos serem de fundamental importância, pois são um dos mais valiosos instrumentos pedagógicos que auxiliam o discente a pensar criticamente, em sala de aula o professor terá maior responsabilidade em abordar e dar maior ênfase a estes assuntos, tendo que utilizar outros recursos didáticos para complementar o ensino. 
Desta forma, levando em consideração o grave problema de saúde público que a resistência bacteriana representa, anseia-se a criação de outras formas didáticas para o ensino desta temática, a fim de poder envolver e estimular o aprendizado do discente para a formação de um cidadão consciente.

\section{REFERÊNCIAS}

AMABIS, José Mariano; MARTHO, Gilberto Rodrigues. Biologia Moderna: Amabis \& Martho. V. 2, 1ª Ed, Ensino Médio, São Paulo: Moderna, 2016.

BATISTA, Marcus Vinicius de Aragão; CUNHA, Marlécio Maknamara da Silva; CÂNDIDO, Alexandre Luna. Análise do tema virologia em livros didáticos de biologia do ensino médio. Ensaio Pesquisa em Educação em Ciências, v. 12, n. 1, 2010. Disponível em: http://www.redalyc.org/articulo.oa?id=129512578009. Acesso em: 26 maio 2019.

BIZZO, Nelio. Biologia: novas bases. Vol. 2, 1ª ed. São Paulo: IBEP, 2016.

BRAOIOS, Alexandre; PEREIRA, Ana Cláudia Souza; BIZERRA, Adaís Alves; POLICARPO, Olmeny Ferreira; SOARES, Nayana Carvalho; BARBOSA, Adriano de Souza. Uso de antimicrobianos pela população da cidade de Jataí (GO), Brasil. Ciência \& saúde coletiva, Rio de Janeiro, v. 18, p. 3055-3060, 2013. Disponível em: http://www.scielo.br/scielo.php?script=sci_arttext\&pid=S141381232013001000030\&lng=en\&nrm=iso. Acesso em: 08 maio 2019.

BRASIL. Catálogo do Programa Nacional do Livro para o Ensino Médio. Secretaria de Educação Básica. Brasília, 2006.

BRASIL. Ministério da Educação. PNLD 2018: biologia - guia de livros didáticos - Ensino Médio. Secretária de Educação Básica - SEB - Fundo Nacional de Desenvolvimento da Educação. Brasília, DF: Ministério da Educação, Secretária de Educação Básica, 2017. 92 p. Disponível em: http://www.fnde.gov.br/pnld-2018/. Acesso em: 26 maio 2019.

BRÖCKELMANN, Rita Helena. Conexões com a Biologia. Organizadora: Editora Moderna; obra coletiva concebida, desenvolvida e produzida pela Editora Moderna. Vol. 2, $2^{\mathrm{a}}$ ed. São Paulo: Moderna, 2016.

CASSANTI, Ana Claudia; CASSANTI, Ana Clara; ARAÚJO, Eliana Ermel; URSI, Suzana. Microbiologia democrática: estratégias de ensino-aprendizagem e formação de professores. Revista Conhecer, v. 9, n. 1, p. 84-93, 2008. Disponível em: http://botanicaonline.com.br/geral/arquivos/cassantietal2008\%20microbiologia.pdf. Acesso em: 29 maio 2019.

CATANI, André; CARVALHO, Elisa Garcia; SANTOS, Fernando Santiago dos; AGUILAR, João Batista; CAMPOS, Sílvia Helena de Arruda. Ser Protagonista: biologia. $2^{\circ}$ ano: Ensino Médio. $3^{\text {a }}$ Ed. São Paulo: Edições SM, 2016.

DANDOLINI, Bruna Werner; BATISTA, Lilian de Bem; SOUZA, Lúcia Helena Fernandes de; GALATO, Dayani; PIOVEZAN, Anna Paula. Uso racional de antibióticos: uma experiência para educação em saúde com escolares. Ciência \& Saúde Coletiva, Rio de 
Janeiro, v. 17, p. 1323-1331, 2012. Disponível em:

http://www.scielo.br/scielo.php?script=sci_arttext\&pid=S1413-

81232012000500026\&lng=en. Acesso em: 10 maio 2019.

ENGELKIRK, Paul Gwendolyn; DUBEN-ENGELKIRK, Janet. Burton Microbiologia para as ciências da saúde. Tradução: Eiler Fritsch Toros. $9^{\mathrm{a}}$ ed., Rio de Janeiro: Guanabara Koogan, 2012.

FAVARETTO, José Arnaldo. Biologia unidade e diversidade. $2^{\circ}$ ano, $1^{\text {a }}$ ed., São Paulo: FTD, 2016.

FRISON, Marli Dallagnol; VIANNA, Jaqueline; CHAVES, Jéssica Mello; BERNARDI, Fernanda Naimann. Livro didático como instrumento de apoio para construção de propostas de ensino de ciências naturais. Encontro Nacional de Pesquisa em Educação em Ciências. Florianópolis. Nov. 2009. Disponível em:

http://posgrad.fae.ufmg.br/posgrad/viienpec/pdfs/425.pdf. Acesso em: 07 Abr. 2019.

LINHARES, Sérgio; GERWANDSZNAJDER, Fernando; PACCA, Helena. Biologia Hoje. Vol. 2, 2ª Ed., São Paulo: Editora Ática, 2016.

LOPES, Sônia; ROSSO, Sérgio. BIO. Vol.2, 3ª Ed. São Paulo: Editora Saraiva, 2016.

MENDONÇA, Vivian Lavander. Biologia: Ecologia: Origem da vida e biologia celular: embriologia e histologia. Vol. 2, 3ª Ed, Ensino Médio. São Paulo: Editora AJS, 2016.

MORAES, Amanda Ludogerio; ARAÚJO, Nayara Gabriele Picanço; BRAGA, Tatiana de Lima. Automedicação: revisando a literatura sobre a resistência bacteriana aos antibióticos. Revista eletrônica Estácio Saúde, Santa Catarina, v. 5, n. 1, p. 122-132, 2016. Disponível em:

http://revistaadmmade.estacio.br/index.php/saudesantacatarina/article/viewFile/2234/1059. Acesso em: 08 maio 2019.

OGO, Marcela Yaemi; GODOY, Leandro Pereira. \#Contato biologia. Vol. 2, $1^{\text {a }}$ ed., São Paulo, Quinteto Editorial, 2016.

OLIVEIRA, Adriana Cristina de; SILVA, Rafael Souza da. Desafios do cuidar em saúde frente à resistência bacteriana: uma revisão. Revista Eletrônica de Enfermagem, v. 10, n. 1, 2008. Disponível em: https://www.fen.ufg.br/revista/v10/n1/pdf/v10n1a17.pdf. Acesso em: 09 maio 2019.

OLIVEIRA, Erika Lira; RIATTO, Sabrina Gonçalves; VIEIRA, Andrê Parente Sá Barreto; CARVALHO, Giovana; FONSECA, Matheus; GUEDES, Victória; PEREIRA, Jackeline; ROCHA, Kaionara. A importância do nível de conhecimento dos professores de escola pública do ensino fundamental sobre saúde bucal-revisão de literatura. Revista campo do saber, v. 4, n. 5, 2019.

ORGANIZAÇÃO MUNDIAL DA SAÚDE (OMS). A crescente ameaça da resistência antimicrobiana. Suíça. 2012. Disponível em: https://afro.who.int/sites/default/files/201706/OMS_IER_PSP_2012.2_por.pdf. Acesso em: 05 de maio de 2019. 
ORGANIZAÇÃO MUNDIAL DA SAÚDE (OMS). Resistência a antibióticos. Suíça. 2018. Disponível em: https://www.who.int/news-room/fact-sheets/detail/antibiotic-resistance. Acesso em: 09 de maio de 2019.

PEREIRA, Francis Solange Vieira Tourinho; BUCARETCHI, Fábio; STEPHAN, Celso; CORDEIRO, Ricardo. Automedicação em crianças e adolescentes. Jornal de Pediatria, Rio de Janeiro, v. 83, n. 5, p. 453-458, 2007. Disponível em: http://www.scielo.br/scielo.php?script=sci_arttext\&pid=S002175572007000600010\&lng=en\&nrm=iso. Acesso em:10 maio 2019.

PÉREZ, Fabio Martinez. A pesquisa qualitativa crítica. In: Questões sociocientífica na prática docente: Ideologia, autonomia e formação de professores [online]. São Paulo: Editora UNESP, 2012, p. 138-152.

SACRISTÁN, Gimeno; GÓMEZ, AI Pérez. Compreender e transformar o ensino. $4^{\mathrm{a}}$. ed. Porto Alegre: Artmed Editora, 2009.

SILVA JÚNIOR, César da; SASSON, Sezar; CALDINI, Nelson. Biologia Vol. 2. São Paulo: Saraiva 2016.

VASCONCELOS, Simão Dias; SOUTO, Emanuel. O livro didático de Ciências no Ensino Fundamental proposta de critérios para análise do conteúdo zoológico. Ciência \& Educação, v. 9, n. 1, p. 93-104, 2003.

Recebido em: 22 de julho de 2019. Aprovado em: 09 de dezembro de 2019. 